\title{
Representation and Construction of Self in Writing Discourses
}

\author{
Mohamad Jamali*, Hamid Najafpour Sani \\ Islamic Azad University, Urmia Branch, English Department, Urmia, Iran, \\ *E-mail adress: mjamali6466@gmail.com
}

\begin{abstract}
The "discoursal self', according to Ivanic, is "the impression. . . they [the students] consciously or unconsciously convey... in a particular written text.. . . [I]t is constructed through the discourse characteristics of a text, which relate to values, beliefs, and power relations in the social context in which they were written" (25). The "autobiographical self," Ivanic explains, "is the identity which people bring with them to any act of writing" (24). The goal for this paper is an overview investigating whether or not students are aware of a discoursal self being constructed for them as a result of being students in another academic environment. The author begins by exploring the theoretical concepts of the socially constructed "self", language and how language is used by society to influence the individual. Further, he narrows the focus and reviews the field of literature by Rhetoric and Composition scholars who have explored the issues and impacts of teaching academic discourse to students. If we attempt to understand what the students think and how they perceive the writing, we may be able to better tailor our assignments, methods and approaches to better fit the needs of the students. The findings and results of my thesis may be of benefit to educators and other professionals across the world. The text will also provide a safe, anonymous, respectable outlet for students to voice their opinions and thoughts.
\end{abstract}

Keywords: Representation; Construction; Self; Composition; Discourse

\section{INTRODUCTION}

\subsection{The Self, Language and Ideology}

When one discusses a "social construction" of identity, there are a few key concepts that should be clarified. A social constructionist theory of identity asserts that individuals are a composite of their interactions with society. For instance, students within the university may be having identities constructed for them by being a part of that particular society. Richard Shweder writes, "The 'social' part of a social construction theory is the idea that categories are vicariously received, not individually invented; and the cognate idea that the way one divides up the world into categories is, in some sense, tradition-bound, and thus transmitted, communicated and 'passed on' through symbolic action" (156). A person's identity or sense of self is constructed as a result of interacting with society and the members within a particular society. This is what the term "social construction" entails: how society constructs the self.

A social constructionist view on identity and person development seems to imply that there is no "intrinsic" self. Instead, the "self' the person acts out is "the kind of 
conceptualization of the person that is presupposed by our social order and a requisite for its functioning" (Shweder 174). Students within the university may act a certain way because the university climate has tacitly or explicitly instructed them to do so. The use of the verb "to act" in relation to the concepts of identity and self has a tradition largely popularized by Erving Goffman. In The Presentation of Self in Everyday Life, Goffman uses the extended metaphor of dramaturgy to explain how people act in society. Students are merely playing the roles of students, and instructors are playing the roles of instructors. Their parts and scripts are handed to them or constructed by the director of the play which would be whoever is in command. This idea belies the notion of an intrinsic "self' because the Oxford English Dictionary defines the "self' as, "That which in a person is really and intrinsically $h e^{\prime \prime}$ (original emphasis). This definition appears to imply that there is a static fixedness within the idea of a person. If a social constructionist theory of self is antithetical to a position of static fixedness, then it may be assumed that a person's sense of self or identity is a product of a particular place or time. Gergen and Davis write, "The terms in which the world is understood are social artifacts, products of historically situated interchanges among people" (5, original emphasis). How one interacts with the external world, other people, is a direct result of being in that particular era and place. How students interact with each other and faculty at a university are the results of attending that specific university at that point in time. A sense of self is highly dependent upon context. This means that social perceptions of how one should interact with the world may change with time. Gergen and Davis mention this by noting how humans interact with each other is dependent upon "the vicissitudes of social processes. . . $[w]$ hether an act is defined as envy, flirtation, or anger floats on a sea of social interchange" (6). People understand what is acceptable as a result of communicating (verbally or nonverbally) with other people.

A major theory that determines what may be acceptable and unacceptable in society is the notion of ideology and how it works within a particular context. The $O E D$ lists the following definition of ideology: "A systematic scheme of ideas, usually relating to politics, economics, or society and forming the basis of action or policy; a set of beliefs governing conduct." Ideology is, simply, beliefs of conduct within a society at a particular time and place. Gramsci writes that ideology is perpetuated through the use of hegemony. Hegemony is what "the dominant group exercises throughout society and on the other hand to that of 'direct domination' or command exercised through the state and 'juridical' government" (1142). Hegemony is the manufacturing of consent which is controlled through a prevailing ideology. Hegemony and ideology were popular concepts among Marxist philosophers of the early twentieth century. In terms of academic discourse, this could mean that a certain select group of individuals determine what is and is not acceptable Discourse within the university. Whereas Gramsci uses the ambiguous terms "State" and "superstructure" to refer to those who exercise hegemonic control, Althusser, another noted scholar of the time, uses a more concrete term, Ideological State Apparatuses.

According to Althusser an Ideological State Apparatus is a medium utilized to perpetuate a certain ideology, to exercise hegemony. Althusser notes that this ranges from institutions as innocuous as "churches, parties, trade unions, families, some schools, most newspapers, [and] cultural ventures. .." to more "repressive" state apparatuses such as "the Army, the police, the courts, [and] the prisons" (1489). The difference between the two is the former exercises control through ideology, mental repression, and the latter exercises control through physical repression. This is not to say that repressive state apparatuses do not enforce a particular ideology. Althusser writes that it is important the repressive state apparatuses enforce an ideology to "ensure their own cohesion and reproduction" (1490). The university 
may institute policies and guidelines that students and faculty are supposed to follow. Entrance exams are an example. If a student receives a low score on an entrance writing exam, she may be placed in a remedial writing course because her writing skills are not to the standards dictated by the university.

Althusser uses the example of a police-officer shouting, "Hey, you there!" in a crowd of people. The author writes, "Assuming that the theoretical scene I have imagined takes place in the street, the hailed individual will turn around. By this mere one-hundred-and-eighty-degree physical conversion, he becomes a subject" (1504, original emphasis). Althusser calls the process of being subjected by society "interpellation" or "hailing." This is how, Althusser writes, society "'recruits' subjects among the individuals. .. or 'transforms' the individuals into subjects" (1504). By imposing its will on the individuals in a society, by transforming individuals into subjects, a society is perpetuating its ideology through this act of hegemony. It can then be assumed that a person is socially constructed as a result of being interpellated by an ideology promoted through hegemony via a state apparatus. Another way of looking at this is a person's sense of self is constructed as a result of popular ideas, beliefs, attitudes and traditions present in a society at a given time that is often promoted by the higher classes. Members of a lower stratum of society (as discussed in Gramsci) will want to gain access to the various higher strata of society. Students entering the university may see their older classmates or instructors as role models and want to be like them. In order to do this, the members of the lower stratum must do and perform whatever those in the higher strata do and perform. One popular way an ideology is perpetuated is through the use of language within a society.

Mikhail Bakhtin, in his studies on the use of language within novels, developed theories on language that pertain to the study of how writing and discourse may affect people. Prior to the publication of his works, language theory was largely dominated by Saussure. Saussure postulated that for every thing (a sign) there is a related concept (a signifier). An example would be to consider the noun, "Tree." The word conjures a very specific image of a plant that grows out of the ground, has a rough bark with branches that either have leaves or needles. However, this concept of language does not take into account the possibility of metaphor and analogy. If someone describes a person as a "Tree," he/she does not mean the other person is actually a tree but rather has the qualities of a tree. With this in mind, Bakhtin developed the concept of "heteroglossia." Heteroglossia allows for a multiplicity of voices to affect a particular language and its lexical units (words).

The reason why heteroglossia works as a concept is because it is related to a social constructionist theory. In regards to a singular, static view of language, Bakthin writes a "unity of style thus presupposes on the one hand a unity of language... and on the other hand the unity of an individual person realizing himself in this language" (264). However, if society is constantly in flux due to the changing ideologies at work in the society, how is a person able to realize "himself' in a particular language that is unified? There might be no unified language. Bakhtin writes that this view of language in relation to the person was "simple and unmediated" because "at every moment of its linguistic life it is opposed to the realities of heteroglossia" (269-270). Language, according to Bakhtin, is situated in a particular context in relation to whatever is the dominant ideology of the time and place. It is not static and as such is subject to change. Ideas regarding academic writing are an example of this. As particular fields of study have developed, they have created their own ways of documenting and presenting a text. This has resulted in styles such as MLA, APA, Chicago and many others that are specific to an individual field of study. These styles change and adapt as new theories and methods arise. 
If language is constantly in flux and subject to the whims of society, then language may reflect a shift in social forces. Much like how individuals in society are stratified, Bakhtin views language as being particularly stratified. He writes, "At any given moment of its evolution, language is stratified not only into linguistic dialects in the strict sense of the word. . . but also. .. into languages that are socio-ideological" (271-272). Within a particular language there are numerous dialects and these dialects are markers of one's position within society. A British accent may be perceived to be more intelligent versus a dialect from the southern area of the United States. A person may be interpellated, to use Althusser's term, depending upon the dialect of language he/she is using. In writing, these dialects are sometimes referred to as discourses. A student's discourse at home, her primary discourse, may not be in agreement with the discourse particular to her university. She has to change her discourse in order to meet the discourse standards of the university. I am curious to see what tension there may be between a student's discourse at home and the discourse she adopts at the university. In chapter 2,1 discuss the possible differences between discourses in more detail.

This stratification, according to Bakhtin, may not necessarily be a bad thing. Bakhtin writes, "[T]his stratification and heteroglossia, once realized, is not only a static invariant of linguistic life, but also what insures its dynamics: stratification and heteroglossia widen and deepen as long as language is alive and developing" (272). Rather than being viewed as a negative force, Bakhtin sees the evolution of language through heteroglossia and stratification as a positive force. It keeps the language alive. While it may be sad to see particular groups of people interpellated negatively because of a certain dialect they speak, the fact is their dialect is particular to that area and group of people and has its own internal structure that follows a certain codified set of rules. However, a problem may be when groups try to dictate, or exercise hegemony, over how a particular language or dialect should function. What this might do is prevent a language from evolving and instead may fossilize the language into a set of rules that a certain group believes is "right" or "correct." Explicitly telling students how they speak or write may be incorrect is an example of this.

Language evolves and changes, according to Bakhtin, as a result of those who speak it. They inject the language with their own definitions, beliefs and ideas: "And into this complex play of light and shadow the word enters - it becomes saturated with this play, and must determine within it the boundaries of its own semantic and stylistic contours" (277). In this sense, the word or utterance is animated and almost seen as alive. What determines whether it will survive and how it will look will be those individuals who choose to use the particular word or utterance. Bakhtin goes on to say, "[T]he social atmosphere of the word, the atmosphere that surrounds the object, makes the facets of the image sparkle" (277). In this sense, language is viewed as a precious object that is not made beautiful until it is animated by the society it permeates.

Similarly, this shows how difficult it is, and how detrimental it may be, to constrain language and perpetuate a prescriptivist ideology. A prescriptivist ideology is one that tries to institute very particular rules on language. These rules are constructed by a group of individuals and then passed down like an ideology. In terms of writing, examples of this may include that it is improper to end a sentence with a preposition or to use the personal pronoun "I" in academic writing.

If language is constantly in flux and being negotiated by those who speak it, language becomes a dialogue. It is this dialogic nature of language that fuels the notion of heteroglossia. Bakhtin asserts that "the dialogic orientation of discourse is a phenomenon that is, of course, a property of any discourse. It is the natural orientation of any living discourse" 
(279, original emphasis). It is interesting to note Bakhtin's choice of words: "natural orientation" and "living discourse." If a language does not fall into that dialogic rhythm, the constant pulling of negotiation, then it may become fossilized and eventually die or be usurped by another language. This could be the potential problem with a prescriptivist ideology in regards to language. Bakhtin writes, "Therefore, insofar as the speaker operates with such a passive understanding, nothing new can be introduced into his discourse; there can be no new aspects in his discourse relating to concrete objects and emotional expressions" (281). If people do not engage in adding to the layers of language, the language eventually stops growing. Bakhtin calls this the "multilayeredness" of language. This simply means language does not have one, static, overarching definition. There are multiple layers within a language, and that is what makes a particular language interesting, and it is ideology that determines these layers. These layers are added on by the societies and generations that fuel a language.

This stratification can be seen as something as simple as jargon. A university or field of study may have a particular way of speaking about things or presenting information. This jargon acts as a gatekeeping mechanism. Those who understand the jargon and are able to integrate the jargon into their own languages are accepted into the community. In the university, students are seeking acceptance into these communities and must learn how to appropriate the language of that community. Bakhtin writes that professional languages, and all languages in general, are intentional and those who do not understand the jargon are viewed as outsiders (289). Gee brings up this issue in his discussion on Discourse and Discourse Communities (see below). In this sense, language is viewed as being imbued with a certain power that can be used for good or bad. Bakhtin confirms this by claiming, "Language is not a neutral medium that passes freely and easily into the private property of the speaker's intentions; it is populated- overpopulated-with the intention of others. Expropriating it, forcing it to submit to one's own intentions and accents, is a difficult and complicated process" (294). However, this is not to say that language is not expropriated and bent to one's will. In fact, it happens more often than not in order to exercise power and control over a group of people.

Norman Fairclough explores this issue in his text, Language and Power. The purpose of Fairclough's text is to explore the problems of language being affected by ideologies that permeate a particular society. The author does this by using a "critical language study" approach to look at how power and society is affected by language, and this is done largely through a critical approach towards studying ideologies. "Ideologies," Fairclough writes, "are closely linked to power, because the nature of the ideological assumptions embedded in particular conventions. . . depends on the power relations which underlie the conventions" (2). Because ideology is context dependent and society constantly changes, the ideologies within a particular society change and affect the role of power. Fairclough goes on to assert that how ideology "legitimiz[es]" power is through repeating "ordinary, familiar ways of behaving" (2). If society does not change, the ideology within that society does not change. Primarily, it is the dominant/the richest class of that society who dictate what is and is not acceptable within that society. Once it reaches the common person, he/she may not think to wonder where the practice originated. "Practices which appear to be universal and commonsensical can often be shown to originate in the dominant class or the dominant bloc, and to have become naturalized' (Fairclough 33, original emphasis). Language is the biggest Ideological State Apparatus, to use Althusser's term, because language "is the commonest form of social behavior" (Fairclough 2). Every person within a society is subject to a particular ideology because by merely being within a society the person is subjugated by the very act of using or 
understanding language. At the university, students may be asked by their instructors via university administrators to write a certain way. As a result, some students may feel their natural ways of speaking or writing are repressed. I am curious to see if students do feel this way.

Fairclough's study is not just limited to speech communication. He is also very much concerned with the role of composing and reading texts within society. Fairclough writes, "[W]e ought to be concerned with the processes of producing and interpreting texts, and with how these cognitive processes are socially shaped and relative to social conventions, not just with texts themselves" (19). If language conventions and norms are constructed by society, then it should make sense that writing is also shaped by society. As a result, the entire communicative sphere is determined by society. When a person is choosing to communicate within a society, he/she has to make certain linguistic choices: "Linguistic phenomena are social in the sense that whenever people speak or listen or write or read, they do so in ways which are determined" (Fairclough 25). Society permeates every thought and decision process. That is how society constructs an individual and imbues her with a certain sense of context. A person will speak, write, or communicate differently in different situations. An example of this is a writing assignment for a composition class. It may be very specific and tell students what conventions to use, what texts to analyze or what genre in which to write. These rules could affect the outcome of the writing assignment.

When a person approaches a text or any reading situation, she draws from her, what Fairclough calls, "members resources (MR)" in order to decide how to best approach the situation. A person's MR is also socially constructed. "These social conditions shape the MR people bring to production and interpretation, which in turn shape the way in which texts are produced and interpreted" (25). As Althusser mentioned (see above), schools can be considered a very effective state apparatus for socially constructing a person's MR and fitting her into her role within society. Fairclough writes, "[I]t is also the case that in occupying particular subject positions, teachers and pupils reproduce them; it is only through being occupied that these positions continue to be a part of the social structure. So discourse in turn determines and reproduces social structures" (38, original emphasis). The very act of being a student hails the particular individual into being a student. This is because the individualasstudent is relinquishing any power to the individual-as-teacher. There is no codified rule that says $\mathrm{X}$ person must be a teacher and $\mathrm{Y}$ person must be a student. They assume their roles, and, as a result, perpetuate those roles. This is done through discourse and the effect of language, particularly writing, on the construction of discoursal selves. In the next chapter, I will review a range of literature by a variety of authors who have written on the issues central to my investigation. They investigate topics such as how writing affects the mind, how university writing policies construct discoursal selves and how there may be tension between a student's primary and secondary discourses. These texts will enlighten the discussion on how students in first year composition are affected by the writing they perform for the university.

\section{DISCUSSION}

When reviewing the field of literature regarding how academic discourse affects students, there are a wide range of opinions and approaches to exploring the topic. While some authors see some benefit in teaching academic discourse to students, other scholars are very much opposed to the concept. Some scholars believe the potential for properly teaching 
academic discourse is through the assignments given in a writing course. David Olson and others have taken to studying the effects of writing and literacy on the mind and the self. In his text, "Writing and the Mind," Olson's main goal is to explore how "forms of writing could have altered, and indeed continue to alter, cognition and consciousness" (108). It is important to try and understand the connection between writing and its effect on the individual. The $O E D$ defines the "mind" as, "The seat of awareness, thought, volition, feeling, and memory... this whole system as constituting a person's character or individuality." It seems the mind is what shapes the self. If this is the case, then the mind receives the impressions from the external world which then construct the self, the outward appearance. How does the process of composing or learning to compose affect the construction of a discoursal self? The author explains this by looking at the relationships between speech and writing and how language and communication have an effect on the brain. Olson's "central claim is that we come to think about our speech, indeed to hear our speech, in terms of the categories laid down by our scripts" (108). He argues that "writing systems provide the concepts and categories for thinking about the structure of spoken language, rather than the reverse" because writing systems "are developed for mnemonic and communicative purposes, but because they are 'read,' they provide a model for language and thought" (110).

This may have a number of implications for how writing affects the mind. According to Olson, writing is modeled after speech because writing "allow[s] language to be seen as composed of words related by means of a syntax" (114). Words by themselves may not have meaning, but if they are situated next to each other and within a particular context (society), they are filled with meaning. This is analogous to Bakhtin's concepts of heteroglossia and the multilayeredness of language. When students interact with their peers and faculty in the university, the language they use, spoken or written, may be determined by the context of the situation. Olson goes on to say that "writing affects consciousness and cognition through providing a model for speech - a theory for thinking about what is said" (121). How one talks influences one's thought processes or her MR. It is the society in which the person exists that determines how she talks and makes linguistic decisions. For instance, a school may act as a society that can determine what linguistic choices a student may make in response to an assignment. Control over linguistic choices and rhetorical events, according to Olson, is how language, in particular writing, affects the mind.

Ong argues the same topic in his text "Writing is a Technology that Restructures Thought." Whereas Olson approaches the concept of writing and the mind from a sociocultural point of view, Ong is more interested in how the individual is affected by writing rather than a whole society. In his text, Ong argues that "writing raises consciousness" and does this through several different ways (23). According to Ong, separation is the most "generalizable" effect that writing has on the individual because it "separates the known from the knower" (24). This is because the whole purpose of academic composition is to illustrate knowledge which the author assumes the audience may be lacking. Having an incomplete knowledge about the audience requires the writer to "invent" her audience. The student is attempting to reach a Active audience in order to display her knowledge of a field in the hopes of gaining acceptance in that community. Writing presents a paradox in that it "distances the word from sound, reducing oral-aural evanescence to the seeming quiescence of visual space" but also "enforces verbal precision of a sort unavailable in oral cultures" (Ong 25-26). Because the student's audience may not be present with the author, she has to take careful steps in order to make sure her audience understands everything she is writing.

Since Ong is focusing on how writing separates and creates binaries or tensions, the author claims that writing promotes a class system or hierarchy within a society. Ong writes, 
"Writing can divide society by giving rise to a special kind of diglossia, splitting verbal communication between a 'high' language completely controlled by writing even though also widely spoken. . . and a 'low' language or 'low' languages controlled by speech to the exclusion of writing" (27). If one is unable to use the "high" language, she may perceive herself differently than if she could use the "high" language. As mentioned in the previous chapter, a student's native dialect or language may not be considered a "high" language, so she is interpellated by members of the high community to not be worthy of their acceptance. This illustrates how writing not only influences the individual but can also act as a gatekeeping mechanism within a particular society.

Akinnaso discusses how societal views on language can shape the individual consciousness and talks about his own experience being interpellated by his community because of how he spoke. Akinnaso defines "individual consciousness" as, "[T]he totality of an individual's knowledge, thoughts, beliefs, impressions, and feelings and the ways these are represented in behavior, especially in speech and writing" (138). Everything that constitutes a person is represented via her individual consciousness, which is then represented by language either in spoken or written form. When a student produces a text, she is drawing from her entire individual consciousness to create that text. That individual consciousness has also been shaped by her interactions with others and how she has been taught to use language. According to the author, literacy is not simply being able to read or write. For Akinnaso, literacy is not just about reading and writing but involves a whole system of being, thinking and doing that differentiates groups from each other (139). In Akinnaso's native African culture, being a literate individual was viewed as being similar to a White man. As the author furthered his education, he became more closely associated with those who produced his knowledge (the White man) than his tribal relatives. Being literate made you a "high" individual. Illiteracy was associated with the native tribe folk.

This view of literacy may contain imperialist overtones. As English and literacy further permeated not only his existence but his village's existence, his cultural identity was soon usurped by this new highly literate identity. Akkinaso writes, "During our own time, the vernacular was meant to disappear in high school (except during indigenous language lessons); you were seriously punished for 'speaking in the vernacular"' (147). As children, the lesson they learned through corporeal punishment is that your native language is only appropriate in certain times and places. This taught the students the concepts of discourse and context albeit in a very harsh and prescriptive way that probably was not made very clear. Students in American classrooms may go through similar, albeit less punitive, instruction. Students who do not speak English as their first language may have a difficult time adapting to the specific discourse of the learning institution. They have to alter their personal discourse in order to fit in.

Akinnaso's concept of literacy being able to raise one's consciousness is very analogous to the points Ong and Olson conveyed in their respective texts. As Akinnaso furthered his education, his thought structure began to change. The native tongue was not viewed as an educated, "high" language. Instead, his native tongue was replaced by what was viewed as the proper language. This view was handed down through an ideology that promoted English as the language of educated or "enlightened" persons. The experience did create a dilemma for Akinnaso. If he learned English, he was outcast from his native society. If he did not learn English, he might not have the opportunities to make a better life. English language learners may

Experience a similar dilemma when they enter the university. The whole point, according to Akinnaso, was "literacy had come to mean. .. a way of life, a way of knowing, a 
way of talking, and a way of doing" (154). For Akinnaso, literacy had permeated every aspect of his being. This fits in with his definition of literacy and how it is not just the simple skill of being able to read and write. For Akinnaso and many others, there is a very close and very real link between writing and identity.

Ivanic is also concerned with how writing affects a person's sense of identity and has made the issue of how writing affects ones identity the primary focus in her text, Writing and Identity: The Discoursal Construction of Identity in Academic Writing. In her text, the author investigates the tension between what she calls the "autobiographical self' and the "discoursal self." The autobiographical self is "the identity which people bring with them to any act of writing, shaped as it is by their prior social and discoursal history"; the discoursal self, conversely, is defined by the author as "the impression-often multiple, sometimes contradictory - which [a writer] consciously or unconsciously conveys of themselves in a particular written text" (24-25). For Ivanic, the discoursal self is socially constructed by the interactions one has had with other people. The discoursal self, in turn, affects the autobiographical self because as one internalizes a new discourse, it affects her whole being: alluded to by the end of the author's definition of the autobiographical self noted above. For instance, before engaging with society, a student is only guided by her autobiographical self. As she engages with society and different groups more, she assumes different discoursal selves depending on the context.

Drawing heavily from Erving Goffman's theory of self-as-performance, Ivanic views the individual-as-writer as a performance too. She says the discoursal self "is the writer-ascharacter, the identity which the writer-as-performer portrays" (25, original emphasis). A writer must make many linguistic choices when undergoing the task of composing; the act of communicating requires a complex understanding of what linguistic choices one has available in her, using Fairclough's term, MR. As Ivanic noted in her definition of the discoursal self, linguistic choices can be made consciously or unconsciously. Ivanic notes, "But identity is not socially determined but socially constructed. This means that the possibilities for the self are not fixed, but open to contestation and change" (12, original emphasis). As noted above by Althusser and Bakhtin, the dominant ideology of that time will determine what is socially acceptable, and what is socially acceptable is subject to the whims of the dominant class. These dominant ideologies socially construct the individual and guide the linguistic or discoursal choices one makes.

Whereas the discoursal self can be consciously constructed by choosing which groups to interact with, the autobiographical self is generally not consciously constructed by the individual. Ivanic writes, "A writer's 'autobiographical self develops in the context of socially constrained access to possibilities for self-hood" (28). A person's socioeconomic status will determine the construction of their autobiographical self. It is important to note that a parent's discoursal self may affect the construction of his/her child's autobiographical selves. If a parent chose to speak in a more educated manner around her child and read books to the child in order to affect the child's development, the parent's decision has affected the child's autobiographical

Self. The difference between the autobiographical self and discoursal self is all determined by the ability to choose. This influences Ivanic's primary argument in her text: "Writing is an act of identity in which people align themselves with socio-culturally shaped possibilities for self-hood, playing their part in reproducing or challenging dominant practices and discourses, and the values, beliefs and interests which they embody" (32). If writing influences one's perception of herself, of her identity, Ivanic is interested in the "How?" and "Why?" One way into analyzing the situation is by looking at what Althusser viewed as one 
of the biggest controllers of ideology: education. Ivanic focuses "on the way in which writing academic assignments causes people to 'change their speech', to take on particular identities, and how they feel about it" (7). Ivanic believes that writing assignments play an important role in the discoursal self construction of students. This is why in my survey, I asked students how they feel about the writing they perform as schoolwork and how it might be affecting their perceptions of themselves.

Ivanic focuses one chapter entirely on how literacy, particularly written literacy, affects the self. Eschewing the typical definition of literacy as simply being able to read and write, like Akinnaso, Ivanic seeks to understand the deeper implications of literacy. She writes, "Written language is still. . a particularly important semiotic system, since it is one which has a gatekeeping function in many social contexts, and the inability to use it according to particular, privileged conventions affects many people's life chances" (58). Here she is making a clear connection between an ability to write and having access to certain discourse communities. If one is born into the primary discourse and already familiar with the discourse of education, then the person has a very strong chance of getting into the college she wants. The author notes that literacy is shaped by pervading ideologies present within a society (59). Literacy, like everything else, is socially constructed, and those social norms, ideologies, determine what is and is not acceptable. These ideologies can affect every linguistic choice a person can make. Ivanic continues by saying, "Each decision a language user makes will be drawing more or less conventionally, more or less creatively, on these norms" (61). Language is contextually situated within the pervading ideology or ideologies at the moment.

As a result, if language is shaped by social norms and conventions, literacy may also be influenced by the ideologies represented in the culture of the communicator. The number of ideologies present in a society can foster a multitude of literacies within a person. Because of this, a person may develop not a singular style, but a multitude of styles approaching Bakhtin's concept of "heteroglossia" (see above). Ivanic writes, "In terms of writer identity, a person has a multiple identity as a writer both as a consequence of participating in a variety of culturally shaped literacy events and as a consequence of employing a variety of culturally shaped practices in those events" (68-69, original emphasis). If a student situates herself in more discourse communities, she will develop more literacies. This will strengthen her toolkit or her MR because she will be more familiar with a variety of rhetorical events. This ability to easily adapt to new rhetorical situations will make the student not only more comfortable but more desirable to other societal institutions (schools, employers, etc.) as well. Ivanic notes this by saying, "What distinguishes students is... the repertoire of resources they bring with them to the task" (70). A greater understanding of what discourse is, explaining how it entails more than just language and how it works within a society may help better prepare students for a number of possible rhetorical events.

Gee explains in "Literacies, Identities, and Discourses," what discourse is by using the same word but with different meanings: "discourse" and "Discourse." The difference is the former simply represents "language in use"; the latter term is a set of "distinctive ways of 'being and doing' that allow people to enact and/or recognize a specific and distinctive socially-situated identity" (160). "Discourse" is more than language. This seems to share some similarities with Akinnaso's definition of "literacy" involving more than just being able to read and write. Discourse with a lower case " $\mathrm{d}$ " is a language, and "Discourse" is how, where and when that language or discourse is used. The Discourse of a particular community's ways of being and doing can range from "using (oral and/or written) language, other symbol systems, thinking, believing, valuing, acting, interacting, gesturing, and dressing" (160). As noted above by Ivanic, a person will participate in multiple literacy events by engaging with 
multiple discourse communities. These discourse communities represent secondary Discourses to the individual. A primary Discourse is "a culturally distinctive way of being an everyday person, that is a nonspecialized, nonprofessional person" (Gee 160, original emphasis). A person's primary Discourse will affect her autobiographical self. Gee defines secondary Discourse as a "Discourse we acquire later in life, beyond our primary Discourse. . . within a more public sphere than our initial socializing group" (161). These secondary Discourses help create a person's discoursal self or selves. As one moves into or out of secondary Discourses, she will have another discoursal self constructed for her by that community. "Secondary Discourses," Gee writes, "are acquired within institutions that are part and parcel of wider communities, whether these be religious groups, community organizations, schools, business, or governments" (161). In a sense, secondary Discourses are what interpellate individuals and construct the identity they present to society. Noted by Ivanic, a secondary Discourse can impact a person's primary Discourse by being introduced to the person early in life; Gee writes, "One way that many social groups achieve an alignment with secondary Discourses they value is by incorporating certain aspects of the practices of these secondary Discourses into the early (primary Discourse) socialization of their children" (161, original emphasis). Similarly, when students enter the university, they may be entering a different Discourse community and may be taught to write like their instructors and professors and, implicitly or explicitly, how to think and behave.

This is the very heart of the matter in Bartholomae's "Inventing the University." The very opening sentence describes exactly what a student has to do when writing in the university: "Every time a student sits down to write for us, he has to invent the university for the occasion - invent the university, that is, or a branch of it, like History or Anthropology or Economics or English" (511). Bartholomae's definition of what a student has to do in order to be fully accepted into the university is similar to Gee's definition of Discourse or Ong's idea of the student's audience being a fiction: the student must not only write and talk like an intellectual, but she must also be an intellectual. They do this by acquiring the academic discourse utilized in the university. Bartholomae writes that students must "appropriate" this discourse "or be appropriated by" the academic discourse. Whether or not the students appropriate or are appropriated by the academic discourse, they may become interpellated as intellectuals because they are situated within a specific society (the university) and are expected to follow the university's rules. The very act of being at a university places them higher on society's ladder than those who are not because society has put a high value on attending college and getting an education.

While Bartholomae's immediate view of academic discourse sets up a binary (appropriate or be appropriated), he does include a third option later in his discussion. If a student chooses to not participate in the academic discourse, this is interpreted as an act of defiance (514). When discussing things like audience, setting, tone and other rhetorical elements, the student has to enter a realm of cognitive dissonance and feign comfort within that area. Bartholomae writes, "Our students. .. have to be appropriate (or be appropriated by) a specialized discourse, and they have to do this as though they were easily or comfortably one with their audience" (515). Although the student may be writing to a particular instructor, the student has to invent means to address or invoke this and other readers. In addition to creating this partly fictional audience, the student must also give the appearance that she is already a member of the discourse community so that her text will be accepted by the already established members of the community which she is trying to enter. To reiterate Goffman's terminology, the student is merely playing the role of a member in the discourse community; the student's success in playing the role will determine whether she is asked for an encore. I 
am interested to see if there is any tension among students trying to acquire the discourse of the university. Bartholomae alludes to the notion of acting by claiming that the learning process within a university "becomes more a matter of imitation or parody than a matter of invention and discovery" (516). Rather than attempting to discover new knowledge and wisdom, students are often mired in what Freire calls the banking concept of education; teachers deposit knowledge, and students regurgitate that knowledge in a manner fitting the discourse community. This, according to Freire and others, is one of the problems with trying to acquire academic discourse.

Ritchie discusses the problem of students acquiring the Discourse of academia in "Beginning Writers: Diverse Voices and Individual Identity." In the article, Ritchie investigates the dilemma composition (and other) teachers face regarding whether or not to teach academic language or let students maintain their individual voices/primary discourses. When looking at the problem, Ritchie first focuses on those who advocate a "new rhetoric" that not only focuses on the "communicative function" of writing instruction but also the "heuristic function" of writing instruction (155). The members of this community are those who advocate students adopt the Discourse of the community they are trying to enter. She writes, "They. .. assert that learning to write in academia is a complex process involving more than learning to imitate the conventions of a particular community" (155). Students are encouraged to engage in how members might think and take into consideration the audience for whom they are writing: becoming critically aware of what they are composing. As a result of this, students are engaging in a dialogue with fellow classmates in order to understand how their texts are being received.

Ritchie also mentions that students create their own voices for academic writing by engaging with other students and their opinions in the classroom (155). By engaging in what the author calls the "dialogic classroom," students are better able to understand how broad and diverse a discourse community might be. Student success in the dialogic classroom, it seems, is determined by their personal histories and past experiences with writing. These experiences in the dialogic classroom add to her MR and repertoire she may draw from in any linguistic event. These dialogues may also affect her discoursal self and cause her to think and write about things differently.

Ivanic and Gee both expressed similar viewpoints to Ritchie's. Ivanic mentioned that students' autobiographical selves may inform how they write. Gee, similarly, expressed that a student's primary discourse may affect how she performs/acquires a secondary discourse. Ritchie echoes these points by claiming, "The personal, educational, and linguistic histories students bring to our classes contribute to the rich texture of possibilities for writing, thinking, and for negotiating personal identity" (157). A student's personal background seems to aid in the construction of their toolkit or MR. When students write, they draw from these experiences that Ritchie mentions. In addition to this, any previous experience with writing will also inform how a student writes in a particular situation: "The assumptions concerning writing that students bring with them to college from their previous education are also constituents of the rich and complicated scene of the writing class" (Ritchie 159).

In regards to the dilemma Ritchie sought to investigate, she writes, "Embracing our conflicting roles in classrooms should lead us, finally, to a clearer view of how we might achieve our goals - empowering students and helping them gain membership in a given community" (172). Ritchie is putting herself on the side that believes it is the composition instructor's responsibility to prepare the student for gaining membership in a new discourse community, to aid in the construction of a new discoursal self. She believes that in order for students to be fully accepted and appreciated by the academic discourse community, students 
should try and make original contributions to the fields and discussions going on within their academic communities (173). By inserting themselves into conversations and practices within their fields, students should be more prepared for the more advanced levels in academia and beyond by introducing them to the concepts of acquiring another secondary discourse and understanding how to work within a new discourse community in order to become a member of that community.

Fernsten agrees with Ritchie but takes a slightly different approach to the issue of acquiring academic discourse. In her text, "Writer Identity and ESL Learners," Fernsten looks at English language learners who are trying to find their voices and writing identities in light of the feedback they receive from their instructors. In this case, Fernsten is looking at how English language learners' self-perception is impacted by feedback from their instructors. This is a salient point to explore and some of the students in response to my survey were concerned with their feedback from instructors and how it might control their writing.

The reason why Fernsten specifically chose ELLs is because they are "too frequently labeled inferior in the same way that speakers of dialects or nondominant forms of English face negative" (45). Fernsten analyzed writing samples provided by a student and found "[s]he, like most students, did not create a single and fixed writer identity but instead created a multiple and conflicting identity in [the] text" (46). This echoes Bakhtin's notions of heteroglossia and the multivoiced self; a person never writes in one unified voice but rather in a multitude of voices. A student draws from her autobiographical self and discoursal selves, her "individual consciousness" as Akinnaso calls it, whenever she approaches a writing task. As a result of being a non-native English speaker, the student in Fernsten's study feels her way of writing is in conflict with how the university would like her to write, and she does not want to "fix" her writing. When teachers tried to revise the student's writing to better fit the discourse, the student became upset because it "ruin[ed] her work, making it not hers" (50). This had multiple implications for teaching, according to Fernsten. The author believes "expressivist assignments allow[] for hybridity, a blending of genres and discourses" (51). This is because an expressivist pedagogy encourages students to maintain or find and develop their individual voices and understand how it interacts within the university. Fernsten believes this would be a step in the right direction for teaching English language learners how to write because it empowers students to be comfortable with their primary discourses.

Englander looks at a similar issue but with professionals instead of students. In her text, "Transformation of the Identities of Nonnative English-Speaking Scientists as a Consequence of the Social Construction of Revision," Englander looks at the effect of the revising process on four well respected scientists from Mexico seeking publication in an English scientific journal. Specifically using Ivanic's term "autobiographical self," Englander is curious to see what is "the impact of revision on the scientist's sense of autobiographical self' (36). According to Englander, many non-English speaking scientists and scholars seek publication in English journals is because it is seen as a sign of greater success. This elevates them within their respective communities. Already successful in the small discourse community, they seek access to a larger discourse community and are often finding it difficult to gain access.

The four Spanish-speaking scientists in Englander's study all had their manuscripts "rejected for reasons that included unacceptable language, although the scientists had all been satisfied with their manuscripts at the time of original submission" (42). All four scientists preferred the original versions of their manuscripts to the heavily revised manuscripts that were ultimately published, similar to the student in Fernsten's study. As a result of having gone through the process, the scientists found "the English scientific article as being simple, straightforward, and direct" (43). The journals did not want long descriptions; they wanted 
tight and concise prose. That was the discourse. Three of the scientists were unaffected by the criticism, but one, Victor, "was clearly shaken by the response he received concerning his original manuscript" (46). When asked why, Victor replied that this was "the twenty-second" article he had published in an English journal, but this was the first time he had felt such an intense reaction to the editors' revisions and edits that it actually made him depressed (46). Even though they had a negative experience, the scientists all acknowledged the necessity to be published in English journals in order to better establish themselves in their respective fields. When students receive feedback from instructors on their writing, it may affect how students approach future writing tasks and even how their discoursal selves are possibly being shaped by the university. An instructor's feedback may not be just commenting on the students' writing, but any other possible way the student is interacting with others.

In a brief article titled, "Imagining a New Kind of Self: Academic Language, Identity and Content Area Learning", Jeffrey Wilhelm asserts that composition instructors, and university instructors in general, do not just teach writing, but should be teaching "the linguistic processes and patterns for delving deeply into and operating upon that content" (44). Wilhelm is explicitly advocating teaching students how to adopt a new, "scholarly" identity and aid in the construction of a new discoursal self. It is not just about vocabulary, but instructors should teach the Discourse, to use Gee's term, so students can act, think and be like the members of that particular academic community. Wilhelm posits that academic language is a part of the "cognitive toolbox" needed to introduce students to "new roles and identities" (44). This is analogous to Fairclough's MR or Delpit's toolkit. Students can increase their "cognitive toolbox" with new tools they can use in any linguistic situation. However, Wilhelm does not explore what possible implications this might have on the students' sense of self or how instructors might actually do this.

Jimenez picks up the task of exploring how teachers might better tailor their curriculum to meet the needs of English language learners. In his article, "Literacy and the Identity Development of Latina/o Students", Jimenez looks at Latina/o students in America who were raised in bilingual contexts and how they became literate individuals. Jimenez notes that teachers who "demonstrate knowledge of [students'] language and cultures and. . . design instruction to build on culturally familiar activities" have a greater success and more positive experience with students (978). As a result of this, students' primary discourses and autobiographical selves are still valued while they are being introduced to their new academic communities. Jimenez writes, "The highest achieving bilingual Latina/o students created multiple connections across and between their two languages" (979). In the institutions I surveyed, having a very diverse population could be a challenge. However, if instructors utilize an approach similar to what Jimenez is advocating, perhaps they will see a greater success when students are able to understand the connections between their primary and secondary discourses and discourse communities.

In addition to observing classes and taking field notes, Jimenez and his researchers conducted interviews with several focal students from each class and some of the teachers. A formative experiment was done in the form of "10 cognitive strategy lessons. .. as the culminating field-based component of this research study" (983). These lessons were to aid students in "eliciting] extended student discourse. . . teaching] students the think-aloud procedure. . . introducing] culturally relevant text and demonstrating] focal reading strategies... [and] assisting] students with word recognition and fluency" (983). What this research study did was seek to illustrate how cultural borderlands might be positive places of inquiry for students, even young students, to explore. Jimenez writes, "The children, and some of the teachers, who participated in this study were shaped and profoundly influenced by their 
experiences in what could be described as cultural borderlands" (983-984). This allowed students to be comfortable exploring their cultural identities in relation to their surrounding contexts. Students were encouraged to become "bilingual, bicultural, and biliterate processors of text" (992). Jimenez is positing that a borderlands approach to instruction, a critical approach to understanding and creating texts and exploring the differences between a student's primary and secondary discourse, is of the most benefit to students.

Valdes also looks at the issue of non-White students acquiring the academic discourse in her text, "Between Support and Marginalisation: The Development of Academic Language in Linguistic Minority Children." The author explores how helpful it is for linguistic minority students to be actively taught academic discourse by educators. Valdes approaches language through a Bakhtinian lens and claims that it seems moot to teach "academic langugage" because language is inherently multi-voiced and constantly changing. This is not to say students should not be taught English. Valdes states quite the contrary and advocates the teaching of English to linguistic minority children (103). She is primarily interested in the specialized discourse that seems to permeate colleges and universities which may be informed by certain ideologies.

Valdes is concerned with answering, "Can academic language be taught to L2 learners, and if so, how?" If academic language is to be taught effectively, Valdes writes, the first step is for the professional communities, the communities students are hoping to gain access to, to codify what they mean by academic discourse in order for students in any community to receive the necessary knowledge (120). This will then influence how ESL instructors and bilingual educators create their curricula. Valdes agrees with Guerra in that ELL students need to be empowered and their voices deserve to be heard. Unfortunately, due to "residential and academic segregation," few students have these opportunities (124). In the end, she advocates "intercultural literacy" as proposed by Guerra which teaches students how to effectively move in and out of different discourse communities or code switch (125). This will allow students to understand that their voices are of value, and they can also approach the academic discourse without fear of being judged. In the study I conducted, a number of students did feel that their primary discourses were not being valued (see chapter 4). Perhaps by exploring these cultural borderlands, the students might feel less alienated.

According to Prendergast, the issue of teaching academic discourse boils down to race and racism within the composition classroom and the university as a whole. In her article, "Race: The Absent Presence in Composition Studies," Prendergast looks at how race is understood and dealt with in the college classroom. In terms of the composition classroom, the author raises two issues. The first issue is that voices of color are being left out of any critical discussions taking place in the classroom and writing assignments. Secondly, these voices should be heard because they have something to say as a result of being dominated.

Instead of encouraging students to explore the borderlands or contact zones like Valdes and Jimenez advocate, Prendergast believes students should investigate where issues of race rise and fade within the university and society as a whole (46). Rather than advocate any sort of "pedagogical imperative," Prendergast leaves her reader with an "explication on the danger of models" (49). One of the reasons she chooses to do this is in the interest of the educator reading her article. She notes how dangerous it is for untenured educators to try a bold teaching approach and risk losing their jobs. Rather than a specific teaching model, what Prendergast hopes educators cultivate after having read her article is "an awareness that... the mechanisms (like racism) that prevent some students from being heard[;] we need to recognize that our rhetoric is one which continually inscribes our students as foreigners" (51). There is a plethora of social and political issues an educator must take into consideration 
when deciding how or why to teach academic discourse to those who may not be familiar with that discourse.

Lisa Delpit makes this the focus of her text, "The Politics of Teaching Literate Discourse." In Delpit's text, the author explores the question of how ethical it is to teach students, particularly ELLs, academic discourse. Her belief seems to be similar to Ivanic's in that students are born with an autobiographical self, or primary discourse, and when they enter school, that autobiographical self/primary discourse is then influenced or replaced by a discoursal self or secondary discourse. As a result, this raises another ethical dilemma for the teacher; Delpit wonders if teachers are "agents of oppression" for trying to teach students to change their discourse (545). For my study, I was curious to see if students considered their teachers "agents of oppression" and felt like their autobiographical selves were being usurped. According to Delpit, the issue of whether or not to teach academic discourse creates a number of potential problems for the teacher and the student(s).

The first problem, according to Delpit, is "people who have not been born into dominant discourses will find it exceedingly difficult, if not impossible to acquire such a discourse" (546). Even though she does not explicitly state it, but students whose first language is not English may have an exceedingly difficult time trying to acquire the discourse. This is similar to what Fairclough meant when he said language can act as a gatekeeping mechanism. If ELLs are unable to acquire the discourse because they were not born in or near it, then they may be excluded from the discourse of power. This is the second problem Delpit anticipates with teaching academic discourse: "[A]n individual who is born into one discourse with one set of values may experience major conflicts when attempting to acquire another discourse with another set of values" (546). Students may experience some tension or face a dilemma, like Akinnaso did, when determining whether or not how much of their primary discourses do they want to possibly be replaced.

Delpit delineates a few key pedagogical steps teachers can take when teaching students about academic discourse and introducing them to the discourse community. First, she says "teachers must acknowledge and validate students' home language without using it to limit students' potential" (553). This would honor the student's primary discourse while teaching her the secondary discourse. Second, Delpit writes that "teachers must recognize the conflict Gee details between students' home discourses and the discourse of school" (553). If teachers are able to do this, then the first step, validating students' primary discourses, should come naturally. This seems to be similar to exploring borderlands and contact zones like Valdes and Jimenez advocate.

Delpit's main point is "acquiring the ability to function in a dominant discourse need not mean that one must reject one's home identity and values, for discourses are not static, but are shaped, however reluctantly, by those who participate within them and by the form of their participation" (552). It seems, according to Delpit, that the politics of teaching literate discourse involve replacing, or usurping, a student's primary discourse with the more valued secondary discourse. While Delpit seems to be against the idea of teaching academic discourse, she does offer some possible in roads for ethically and respectfully teaching academic discourse. There are some theorists, however, who believe academic discourse should not be taught at all because it is a form of linguistic imperialism.

Canagarajah expresses her opposition towards the teaching of academic discourse in her text, Resisting Linguistic Imperialism in English Teaching. Canagarajah represents a branch of linguistics sometimes referred as "critical linguistics." She is looking at the teaching of English in third-world countries as an imperialist force that promotes the standard of "English as the norm" (3). By utilizing a critical stance, Canagarajah hopes to break the "cyclical 
process" of values being passed from the schools, which espouse Anglo norms, to the students (23). Similar to Delpit, Canagarajah is concerned with honoring and respecting a student's primary discourse and autobiographical self. By teaching academic discourse as the norm, Canagarajah calls this "linguistic hegemony" because it perpetuates an ideology that a thirdworld country's Discourse, in her study's case it was Sri Lanka, is not acceptable (41).

The author goes on and spends some time looking at the history of resisting the teaching of English across the world and uses this historical background to establish a precedent for the immorality of teaching academic English. These historical tensions are continued in the modern classroom, perpetuating the cycle of linguistic imperialism. Students and teachers push and pull over competing discourses. Canagarajah believes "the classroom is a significant site in the reconfiguration of larger social structures and processes" (197). The author seems to agree with Delpit in that primary discourses should be honored while teaching English because it "makes periphery subjects linguistically competent for the culturally hybrid postmodern world they [students] confront" (197). Canagarajah does list some possible activities that can be used to include primary discourses which include small group exercises, pairing English proficient students with non-proficient students, "encouraging the use of bilingual dictionaries" and encouraging students to maintain journals where they write in their primary discourses (193). She does not list many pedagogical practices but rather pedagogical theories about the classroom as being a "site [that] enables students to express subtle forms of opposition to classroom ideologies without jeopardizing their chances of academic success by openly resisting the institution" (192). By following this practice, students' primary discourses may be honored while still learning the secondary discourse of the academic institution.

Bartolome, along with Canagarajah, is another scholar who disagrees with how academic discourse is being taught to students. She writes in the opening of her book, The Misteaching of Academic Discourse, "The education of low-status linguisticminority students in the United States can be generally characterized as a form of miseducation that continues to produce an unacceptably high rate of failure" (1). This miseducation is the notion that students must be proficient in reading and writing English in order to achieve academic success. ELLs who have a difficult time acquiring the language could have a disadvantage. Bartolome refers to Macedo by calling this miseducation a "pedagogy of entrapment" (3). The use of "entrapment" here refers to ELLs having a difficult time acquiring the academic discourse, resulting in limited success. Fueling this notion of English as the language of success is an ideology that reflects many of the values Bakhtin saw in language. The "dominant ideology" that may be perpetuated is that non-English, non-mainstream discourses are of little to no value (Bartolome 4). This creates a stratification of language much like what Bakhtin said. It also echoes the experience Akinnaso went through when he attended school. He quickly saw more economic value placed on English than his native, tribal language.

The problem is whether or not teaching academic discourse is replacing the student's primary discourse. Bartolome says that doing so could have "psychological ramifications that can be far-reaching and yet are largely ignored by most teachers" (11). These ramifications include resistance to the teaching of the language and, as a result, unproductive tension between teacher and students with which Canagarajah was concerned. Bartolome writes that teachers should be "creating classroom contexts that are safe and conducive to critique, analysis, and reflection" (26). This is similar to what Canagarajah espouses in order to create a classroom that values primary discourses.

Bartolome then goes on to describe what she believes is the ideal learning environment. The teacher should act as a "cultural mentor" (47) who is comfortable helping students maintain their primary discourses while acquiring the secondary discourse; Bartolome calls 
this a "maintenance" model of education rather than a "transitional" model (48). The parents should also be involved with their children's education (60). If students are receiving support from their parents and from their teachers, the students may be more encouraged to learn. Ideally, according to Bartolome, the classroom would be bilingual, which would value both the primary discourses of the students and the secondary discourse they are hoping to obtain (49).

Bartolome, like Canagarajah, believes teachers should create a classroom environment that is skeptical of a language hierarchy. Bartolome writes, "A critical sociocultural view of language and literacy promotes objective examination of literate discourse patterns in different cultures and avoids ethnocentricity. . ." (117). If the teacher is more aware of the hierarchies and ideologies that seem to pervade the teaching of academic discourse, then it is assumed she, the teacher, will honor and appreciate students' primary discourses. The goal for Bartolome is not to replace students' primary discourses but to add to their toolkits or MR. While she does not explicitly state any specific pedagogical approaches or assignments, there is a growing body of research that believes expressionist assignments and pedagogies are a valuable tool for honoring students primary discourses.

Bilton and Sivasubramaniam look at how expressive writing can be used in the classroom to facilitate student comfort with writing. The authors see writing that is currently produced in the classroom as "a burdensome experience" that "alienate [s] students from writing" (302). This is because the writing students do in many classrooms is not engaging and does not involve the student herself. The authors specifically state that "student creativity, development of narrative voice and decision-making have all been banished from the writing classroom" (302). Instead, Bilton and Sivasubramaniam espouse an Expressivist pedagogy. The authors write, "The Expressive School viewed writing as an act of creative expression and focused on sincerity, integrity, spontaneity and originality in LI classroom writing" (303). Expressivism was a movement largely championed by Peter Elbow and his colleagues. Expressivist writing "encouraged students to discover themselves through language" and to write "without any interruption" (Bilton 303). With this in mind, it seems like an Expressivist pedagogy could be beneficial for ELL students because it might encourage them to explore how they use language and how they are defined by language.

The authors conducted their study at Bahrain University and sought to answer two questions: "Will this kind of experiment motivate EFL students to become more involved writers?" and "Will expressive writing foster educationally valued qualities?" (304). The students involved in the experiment had to respond to a selection of readings over the course of ten weeks. Students were asked to respond to questions such as "What/why did you like/dislike about the text?", "What were your first impressions of the text?" and "Did you want to read more? Give reasons" (305). The belief was this would promote student response and encourage them to explore the texts and how they interacted with the texts. The frequency of easy writing tasks was thought to "promote self-discipline" (306) among the students. After gathering data from the students over the course of the semester, the authors wrote, "[0]ur students have used their writing to question their own social identity, and therefore they have attempted to develop new conceptual ways of thinking about themselves, their world and the 'others' in it" (315). The researchers became aware of the fact that students began to question their socially constructed identities as a result of engaging in writing activities that encouraged them to explore and understand how they related to the texts they had to read for class. As a result, the researchers found the students became better critical readers and developed a deeper appreciation for writing (316). 
In an article written by Waterman, Kohutis and Pulone during the late 1970's in Developmental Psychology, the authors found that expressive writing was beneficial to students in order to form a better sense of identity. Specifically, the researchers found more value in creative writing, such as poetry, rather than journaling. In terms of identity development, Waterman and his colleagues wrote, "[SJtudents who were currently writing poetry were significantly more likely to be in the identity achievement status" (286). This is because, according to the authors, creative writing encourages students to explore their selves and reflect on how to depict something using text (287). Journaling can just be done as a record of a day's events; there is no impetus for introspection.

The researchers found students who wrote poetry were better able to navigate crises than those who chose to write in journals. This may be because creative writers are more interested in receiving feedback than those who write in journals. That feedback may be "instrumental in helping them to work through their identity crises" (287). While the article is rather outdated, it does set a precedent for illustrating the benefits of expressive writing for students in negotiating their identities. Creative writing allows students to exercise their voices and maintain some autonomy from the academic discourse they are being taught in the university.

\section{CONCLUSION}

While it seems many students do not perceive their discoursal selves being constructed by the new academic setting, it does not mean it is not happening. As a result of being members of a society, students are constantly engaging with and experiencing tension with secondary discourse communities. Tension may manifest itself in dilemmas such as the one Akinnaso faced. Students may have to reconcile their primary discourses with any secondary discourse community. These may be discourse communities they are seeking access to (professional, educational, etc...). If students are seeking access to these discourse communities, they may have to change their own Discourses in order to gain acceptance. In Bartholomae's words, they may have to "invent" the setting. Sometimes this involves putting aside a primary discourse, and sometimes a student is able to integrate her primary discourse into the new secondary discourse. Overall it seems students do not seem to feel like their primary discourses or autobiographical selves are being usurped. However, students were critical in regards to the practices and assignments going on within the classrooms. Educators should be aware of this and perhaps tailor their curriculum to better fit the individual needs of the students in their classes. If this happens, students may become more responsive to their instructors and begin to see possible connections between composition and their lives outside of the classroom and university.

Whether or not instructors want to include a more Expressivist pedagogy in their classrooms is up to them. There does seem to be a case and some merit to including some creative writing in the classroom but probably not as a major assignment. As educators, the primary goal of the composition instructor is to prepare her students for writing at the university level. If poem writing, joumalling or writing narratives makes her students more comfortable before approaching a serious writing task or becoming more familiar with their own writing processes, then I encourage such an approach. Bilton and Sivasubramaniam conclude that students who partake in an Expressivist curriculum or a curriculum that has a few expressivist assignments become "both appreciators and, ultimately, exponents of good 
writing" (318). This is because an Expressivist pedagogy allows students to interact with each other and allow for that deep exploration which is possible through writing.

Teachers should survey their classes at the beginning of the semester or quarter to gather some information about their students and what expectations they may have of the class, themselves and the instructor. What kind of writing do students like? How do the students see themselves as writers? What skills would they like to learn? What are they good at? These are questions I think should be asked. If concern is shown towards the students as individuals, perhaps they will feel more ownership in the class and approach the class more positively. Using any of the surveys like the Writer Self Perception Survey, an inventory similar to Lavelle and Zuercher could yield massively important information. To understand what writing backgrounds the students have we can also ask: Did they enroll in any remedial writing courses? What kinds of discussions do they have in class? What kind of feedback helps them the most? Being concerned and interested in students' thoughts and opinions may help students like ELLs who may not have been born as close to the discourse community of the university and are perhaps more intimidated by acquiring the new discourse. If we can ease their transition into the university, perhaps they will be more responsive and feel more comfortable in the classroom. An easier transition into the college discourse community may help create a more positive environment which could also lead to more positive writing experiences.

\section{Representation and Construction of Self in Writing Discourses}

[1] Goffman, Erving. The Presentation of Self in Everyday Life. Garden City, NY: Doubleday, 1959. Print.

[2] Gramsci, Antonio. "The Formation of the Intellectuals." The Norton Anthology of Theory and Criticism. Ed. Vincent B. Leitch. New York: Norton, 2001. 1138-143. Print.

[3] Ivanic, Roz. Writing and Identity : The Discoursal Construction of Identity in Academic Writing. Amsterdam: John Benjamins, 1998. Print.

[4] "Discourses of Writing and Learning to Write." Language and Education 18.3 (2004): 220-245. MLA International Bibliography. Web. 31 Mar. 2011

[5] Jimenez, Robert T. "Literacy and the Identity Development of Latina/o Students." American Educational Research Journal 37.4 (2000): 971-1000. JSTOR. Web. 29 Nov. 2009

[6] Lavelle, Ellen, and Nancy Zuercher. "The Writing Approaches of University Students." Higher Education 42.3 (2001): 373-91. JSTOR. Web. 10 Jan. 2011

[7] Ong, Walter J. "The Writer's Audience Is Always a Fiction." Cross-talk in Comp Theory: A Reader. Ed. Victor Villanueva. Urbana, IL: National Council of Teachers of English, 2003. 55-76. Print.

[8] "Writing is a Technology that Restructures Thought." Literacy: A Critical Sourcebook. Ed. Ellen Cushman. Boston, MA: Bedford/St. Martin's, 2001. 19-31. Print.

[9] Prendergast, Catherine. "Race: The Absent Presence in Composition Studies." College Composition and Communication 50.1 (1998): 36-53. JSTOR. Web. 29 Nov. 2009.

[10] Ritchie, Joy S. "Beginning Writers: Diverse Voices and Individual Identity." College Composition and Communication 40.2 (1989): 152-74. JSTOR. Web. 6 Aug. 2011. 
[11] Shweder, Richard A. Thinking through Cultures: Expeditions in Cultural Psychology. Cambridge, MA: Harvard UP, 1991. Print.

[12] Valdes, Guadalupe. "Between Support and Marginalisation: The Development of Academic Language in Linguistic Minority Children." International Journal of Bilingual Education and Bilingualism 7.2 (2004): 102-32. Print.

[13] Waterman, Alan S. "The Role of Expressive Writing in Ego Identity Formation." Developmental Psychology 13.3 (1977): 286-287. MLA International Bibliography. Web. 28 July 2011.

\section{References}

[1] Akinnaso, F. Niyi. "Literacy and the Individual Consciousness." Cross-talk in Comp Theory: A Reader. Ed. Victor Villanueva. Urbana, IL: National Council of Teachers of English, 2003. 138-155. Print.

[2] Althusser, Louis. "Ideology and Ideological State Apparatuses." The Norton Anthology of Theory and Criticism. Ed. Vincent B. Leitch. New York: Norton, 2001. 1483-508. Print.

[3] Bakhtin, Michail M. The Dialogic Imagination: Four Essays. Ed. Michael Holquist. Austin: U. of Texas, 2008. Print.

[4] Bartholomae, David. "Inventing the University." Cross-Talk in Comp Theory: A Reader. Ed. Victor Villanueva. Urbana, IL: National Council of Teachers of English, 2003. 623-55. Print.

[5] Bartolome, Lilia I. The Misteaching of Academic Discourses.Tthe Politics of Language in the Classroom. Boulder, CO: Westview, 1998. Print.

[6] Bilton, Linda. "An Inquiry Into Expressive Writing: A Classroom-Based Study." Language Teaching Research 13.3 (2009): 301-320. MLA International Bibliography. Web. 27 June 2011.

[7] Canagarajah, Athelstan Suresh. Resisting Linguistic Imperialism in English Teaching. Oxford: Oxford U.P, 2008. Print.

[8] "The Place of World Englishes in Composition: Pluralization Continued." College Composition and Communication 57.4 (2006): 586 - 619. JSTOR. Web. 7 Feb. 2012

[9] Delpit, Lisa. "The Politics of Teaching Literate Discourse." Cross-talk in Comp Theory: A Reader. Ed. Victor Villanueva. Urbana, IL: National Council of Teachers of English, 2003. 545 - 54. Print. 
[10] Fairclough, Norman. Language and Power. London: Longman, 1989. Print.

[11] Fernsten, Linda A. "Writer Identity and ESL Learners." Journal of Adolescent \& Adult Literacy 52.1 (2008): 44-52. MLA International Bibliography. Web. 7 Apr. 2011.

[12] Freire, Paulo. Pedagogy of the Oppressed. New York: Continuum, 2000. Print.

[13] Gergen, Kenneth J., and Keith E. Davis. The Social Construction of the Person. New York: Springer- Verlag, 1985. Print. 